\title{
海外駐在記事
}

\section{ドイツ カイザースラウテルン駐在記}

\author{
新倉 雄大 [(株)日立製作所 研究開発グループ〕
}

\section{1. はじめに}

著者は共同研究のため, 2018 年 4 月から 2020 年 3 月ま で, ドイツはカイザースラウテルン（フランクフルトから 南西に約 $100 \mathrm{~km}$ ) にあるドイツ人工知能研究センター (Deutsches Forschungszentrum für Künstliche Intelligenz, 以下 : DFKI）に駐在した。本稿では DFKI での研究や当時 の体験について紹介する。

\section{2. カイザースラウテルンについて \\ カイザースラウテルンはドイツ南西部にあり, フランス} 国境にもほど近い，人口約 10 万人の地方都市である。市内 には私が駐在していた DFKI の他にも, マックス・プランク 研究所やフラウンホーファー研究機構など, 数多くの研究 機関が施設を構えている。また，東京都文京区と姉妹都市 の関係にあったり，ヨーロッパでも有数の規模を誇る日本 庭園を有していたりなど，日本との繋がりを感じることの 出来る都市でもある。

\section{DFKI での研究}

DFKI は 1988 年に官民パートナーシップモデルに基づい て設立された, 非営利の研究機関である。筆者の滞在して いたカイザースラウテルン以外にも, ザールブリュッケン, ブレーメン, ベルリンなどドイツ国内のいくつかの都市に 研究施設を抱えており，人工知能を活用したソフトウェア 技術の研究開発においては世界有数の研究機関である。

DFKI で働いている研究者たちは国際色豊かであった。 実際ドイツを中心とするヨーロッパ各国をはじめ, エジプ ト，インド，パキスタン，ヨルダンなど様々な国からやっ てきた研究者たちとやり取りをする機会に恵まれた（公式 サイトによれば DFKI には現在 65 力国以上の国から 1200 人以上の研究者や大学院生が集っているとのことである)。 技術的な議論はもちろん, よりプライベートな価值観や人 生観についても会話できたことは自分の視野を広げる上で とても価值のある時間だったと感じている。

ちなみに, 筆者の DFKI での研究は主にウェアラブルセ ンサを用いた人行動認識に関する研究である。具体的には, ウェアラブルセンサをつけた人の姿勢を認識し, 姿勢に応 じた負荷の大きさを推定するといった内容である。この技 術を用いて作業者の負荷情報を可視化することにより，ど の作業にどんな負荷がどのタイミングで発生しているかが わかるため, 作業内容を改善したり，作業現場そのものを改 善するといったことが期待できる。また, 各作業者の負荷状 況に応じてダイナミックに作業の振り分けをするといった ことも実現可能であると考えている。詳細が気になる方は 動画（https://www.youtube.com/watch?v=Rj4QnCZw6I8）

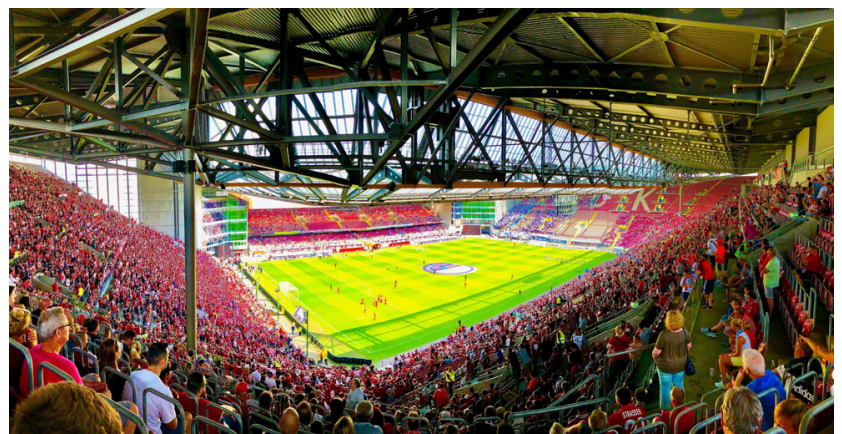

図1 サッカースタジアムの様子

をご覧いただければ幸いである。

4. カイザースラウテルンでの生活について

筋金入りのサッカー好きの方であれば御存知かもしれな いが, カイザースラウテルンはサッカー人気の高い都市で ある。事実, 地元のサッカーチームである 1. FC カイザー スラウテルンは過去 4 度ドイツリーグでの優勝経験もある 古豪で, 現在は 3 部リーグではあるものの, シーズン開幕 戦には 4 万人以上の観客が押し寄せるほどの人気であり, 試合のある日には街中にサポーターが溢れていた。ちなみ に, 2006 年のサッカー $\mathrm{W}$ 杯ドイツ大会では, 日本代表とオ ーストラリア代表がカイザースラウテルンで試合をしてい る(試合は 1-3 で日本の敗戦)。

先にも述べた通りカイザースラウテルンは地方都市なの で, 市内で楽しめる娛楽などはあまり多くない。幸いフラ ンクフルトまで車で 1 時間強なので, しばしば車でフラン クフルトまで行ったり, さらには飛行機に乗ってヨーロッ パ内を旅行したりなどもしていた。フランクフルトに向か うアウトバーンを走行中, 遠くに見えるなだらかな丘の上 に風力発電用のタービンが数多く並んでいた景色が印象に 残っており, 実際全発電量に対する風力発電の占める割合 は約 $20 \%$ ぼある。最近ではドイツを含む欧州の電力不足 などが報じられているが, 私が住んでいた頃は電力供給に 関して特に問題となることはなかったと記憶している。

\section{5. おわりに}

以上，私の駐在体験を簡単に記した。本来は 2021 年 3 月 までの駐在を予定していたが, 新型コロナウイルスの感染 拡大もあり早期の帰任となった。現地の急速な感染拡大を 受け, 現地で一緒に働いた研究者や友人達と挨拶する間も ないまま帰国してしまったことが心残りである。いつの日 かコロナ禍が収束し, 再度現地を訪問して知人達と旧交を 温められる日が来ることを願っている。

(2021 年 12 月 1 日受付) 